\title{
Developing Health Literate Businesses: A Qualitative Study
}

Citation for published version (APA):

Sorensen, K., Czabanowska, K., \& Brand, H. (2015). Developing Health Literate Businesses: A Qualitative Study. Occupational Medicine \& Health Affairs, 3(5), [1000216]. https://doi.org/10.4172/23296879.1000216

Document status and date:

Published: 01/01/2015

DOI:

10.4172/2329-6879.1000216

Document Version:

Publisher's PDF, also known as Version of record

Document license:

Taverne

Please check the document version of this publication:

- A submitted manuscript is the version of the article upon submission and before peer-review. There can be important differences between the submitted version and the official published version of record.

People interested in the research are advised to contact the author for the final version of the publication, or visit the DOI to the publisher's website.

- The final author version and the galley proof are versions of the publication after peer review.

- The final published version features the final layout of the paper including the volume, issue and page numbers.

Link to publication

\footnotetext{
General rights rights.

- You may freely distribute the URL identifying the publication in the public portal. please follow below link for the End User Agreement:

www.umlib.nl/taverne-license

Take down policy

If you believe that this document breaches copyright please contact us at:

repository@maastrichtuniversity.nl

providing details and we will investigate your claim.
}

Copyright and moral rights for the publications made accessible in the public portal are retained by the authors and/or other copyright owners and it is a condition of accessing publications that users recognise and abide by the legal requirements associated with these

- Users may download and print one copy of any publication from the public portal for the purpose of private study or research.

- You may not further distribute the material or use it for any profit-making activity or commercial gain

If the publication is distributed under the terms of Article $25 \mathrm{fa}$ of the Dutch Copyright Act, indicated by the "Taverne" license above, 


\title{
Developing Health Literate Businesses: A Qualitative Study Kristine Sørensen ${ }^{1 *}$, Katarzyna Czabanowska², Helmut Brand ${ }^{2}$ \\ ${ }^{1}$ Maastricht University, The Netherlands \\ ${ }^{2}$ Department of International Health/CAPHRI, Maastricht University, the Netherlands
}

\begin{abstract}
Purpose: In recent years, health and healthy living have become increasingly important issues both in society at large and in the workplace. This study aims to explore how multinational companies develop health literacy strategies in the realm of corporate social responsibility to promote health at work and healthy living.
\end{abstract}

Methods In-depth, semi-structured interviews were made with key staff in 14 multinational companies possessing knowledge on the business' health initiatives and analysed to develop a grounded theory.

Findings The study resulted in a three- tiered theoretical model implying that in order to improve health literacy businesses should make a clear strategic choice and incorporate health at work as a core value. Health programmes should be based on strategic policies and integrated in core business, rather than as independent health projects. The approach should be sustainable and match the needs of employees including health literacy as an explicit target. Health literacy outcomes should be measured and evaluated to follow the progress and ensure a proper fit between actual needs and the efforts undertaken.

Societal implications: A mind shift is needed at business level to encourage health literate decisions not only in the fitness room, but also in the boardroom as part of corporate social responsibility.

Originality: As only scarce research exists on health literacy and corporate social responsibility, the generated theory provides new perspectives for business actions on health literacy to promote health at work and healthy living.

Keywords: Health literacy, Occupational health, businesses, CSR

\section{Introduction}

The concepts of health literacy and corporate social responsibility (CSR) are emerging areas of action for multiple stakeholders promoting health at work and healthy living [1]. Recent research indicated that limited health literacy negatively influences health outcomes [2,3], and these findings are supported by the European Health Literacy study [4]. The study revealed that almost one out of every two individuals exhibits limited health literacy. The wide spread prevalence of limited health literacy has also been described as the 'silent epidemic' [5].

Health literacy is closely linked with human sustainability and the quality of life. It concerns the capacity to make sound health decisions in the context of everyday life - at home, in the community, in the workplace, in the health-care system, in the market place, and in the political arena [6]. The general concept involves peoples' knowledge, motivation and competency to access, understand, appraise and apply information in order to form judgments and make decisions in everyday life in terms of healthcare, disease prevention and health promotion so as to improve the quality of life during the course of life [7].

By including health literacy as part of a business' CSR, companies can create health literacy-friendly working environments and support the workforce to become more health literate to mobilize a healthy and sustainable workforce [1]. The European Commission defines CSR as "the responsibility of enterprises for their impacts on society" [8]. The definition emphasizes the importance of companies initiating a process to integrate social, environmental, and ethical human rights and consumer concerns into their business operations and core strategy. It is generally recognized that CSR, at the very least, encompasses human rights, labor and employment practices such as training, diversity, gender equality and employee health and well-being [8].

Globally and at European level, there is strategic demand for public, private and civil society stakeholders to engage in health and wellbeing at work to support healthy living such as outlined by the World Economic Forum (WEF): "Workplace health promotion programs can promote healthy behaviors through incentives such as work place health screenings, promoting smoke-free workplaces or by providing healthy food options. Employers benefit from these programs through increased employee productivity, improved corporate image and reduced healthcare costs. At a higher system level, healthy labor implies secure and sustainable employment which significantly impacts the well-being and health of the population" [9]. According to the World Health Organisation (WHO) "Health at work and healthy work environments are among the most valuable assets of individuals, communities and countries. Occupational health contributes positively to work motivation, job satisfaction and to the overall quality of life of individuals and society" [10]. In addition, the European Union (EU) in its Europe 2020 strategy aims for a smart, sustainable and inclusive economy to deliver high levels of employment, productivity and social cohesion for the current and future generations to continue enjoying a high-quality of health life [11]. In this regard, the WEF emphasizes that "education and communication are important to build health literacy and strengthen the population-level knowledge on the links between everyday behaviors and health" [9].

However, healthy living is influenced and challenged by several

*Corresponding author: Kristine Sørensen, Assistant Professor, Departmen of International Health/CAPHRI, Maastricht University, the Netherlands.Tel: +31433881717; Fax +31 433881717; E-mail: k.sorensen@maastrichtuniversity.nl

Received July 03, 2015; Accepted October 02, 2015; Published October 09, 2015

Citation: Sørensen K, Czabanowska K, Brand H (2015) Developing Health Literate Businesses: A Qualitative Study. Occup Med Health Aff 3: 216. doi:10.4172/23296879.1000216

Copyright: ( 2015 Sørensen K, Czabanowska K, Brand H This is an open-access article distributed under the terms of the Creative Commons Attribution License, which permits unrestricted use, distribution, and reproduction in any medium, provided the original author and source are credited. 
global megatrends such as demographic change decreasing the workforce, an increase in non-communicable diseases as well as socio-economic inequalities [9]. In addition to these extrinsic factors, fundamental challenges in the workplace itself such as: i) the continuing distribution of organizations; ii) the availability of enabling technologies and social collaboration tools; iii) the upcoming shortage of knowledgeable workers; iv) the demand for work flexibility; and v) pressure for more sustainable organizations and work styles [12] affect health at work. In turn these demands require new and innovative way of thinking concerning 'workplaces of tomorrow' [13]. Although, an employee with few health risks spends less money on medical care due to fewer chronic illnesses and avoided serious health events; many employers still consider poor employee health to be a fringe issue, not a true business issue [14]. Yet, the medical costs are not the primary outcome of poor health, because healthy employees not only cost less in medical care, they are also more functional at work, absent less often, experience fewer injuries, and arrive back on the job more quickly after they do get injured [15]. These factors are impacting not only the healthcare cost account concerning human resources, but also business actions and outcomes in general; therefore health should be considered a core business issue as it impacts core business outcomes [14]. In this regard, the perspective of occupational health is not sufficient, rather health should be pursued within a broader mindset associated with CSR [16]. Along these veins this paper presents a grounded theory on how businesses can actively contribute to the advancement of health literacy as a part of their CSR to promote and sustain health at the workplace. The findings add to the evidence base on how health literacy strategies can potentially be shared and adapted to the broader business community in support of implementing the visions on healthy living as described in the various health related strategies of international organisations such as WHO, EU and the WEF $[9,11,17,18]$.

\section{Methods}

The study assumed a grounded theory approach based on the thematic analysis of the data obtained from the semi-structured indepth, telephone interviews. According to Creswell, grounded theory is "a qualitative strategy of inquiry in which the researcher derives a general, abstract theory of process, action, or interaction grounded in the views of participants in a study" [19]. Thematic analysis is a conventional practice in qualitative research which involves searching through data to identify any recurrent patters [20]. A theme is a cluster of linked categories conveying similar meanings and usually emerges through the inductive analytic process which characterizes the qualitative paradigm. The process of data analysis includes three steps: 1) Open coding: identifying and categorizing phenomena found in the text, 2) Axial coding: fitting themes into a basic frame of generic relationships, and 3) Selective coding: developing a single storyline ('grounded theory') [21] The interviews were made with business members of CSR Europe, which is the leading European business network for corporate social responsibility [22]. A web-based pre-study identified 34 suitable companies among the 75 business members, which actively positioned themselves to be engaged in health and wellbeing at work. Further details concerning the pre-study are described elsewhere by Sorensen and Brand [1]. Of the 34 companies contacted; 14 confirmed their participation, while five rejected with the argument that they did not know enough about health literacy and rather wanted to learn from the outcomes of the study than taking part. 15 did not respond to the request in spite of receiving an additional invitation. The nonresponse was mainly assumed to be the same reason as the five companies which had rejected. Two trained interviewers; from
Maastricht University and CSR Europe respectively (VS and CN), conducted the interviews in September-November 2011. They had different professional backgrounds; one in corporate social responsibility and the other in European public health. Taking into account that the differences could influence the way questions in the semi-structured interviews were asked; ongoing dialogues and briefings took place after every interview to ensure a coherent approach in the data collection. The designated respondents from the 14 participating multi-national companies worked in the area of human resource management and corporate social responsibility. The interview time varied between 10-60 minutes depending on the richness of information provided. The semistructured interview guide (Table 1) included open-ended questions to obtain information concerning specific issues such as descriptions of company related health literacy activities; the attributed financial and human resources, quality insurance; and transferability of the health activities as potential 'good practices' for other companies.

The interviews were recorded and transcribed verbatim before being analyzed with NVivo (Version 9), which is a code-based theory builder software package which includes the capacity to code, retrieve and assist in developing theoretical connections between coded concepts or themes [23]. The data regarding consumers and community engagement was omitted from the analysis since this study focused on work related initiatives for employees only. The three step iterative coding process was made by KS until theoretical saturation occurred, when no new information or themes were emerging from the data and when the grounded theory was thoroughly validated with the collected data [24]. Recognizing that the initial three step coding was performed by one investigator (KS) only, the three tiered theory was reviewed by the interviewers and key stakeholders from CSR Europe (the Joint Venture on Health Literacy) to ensure its rigor. Furthermore, to judge the standard of the qualitative data the trustworthiness criterion including: credibility, dependability, confirmability and transferability was applied $[25,26]$. Ethical aspects were embraced by briefing respondents and asking for informed consent to use the data for research purpose. Interviewers were informed to respect confidentiality and acknowledge if respondents wished to stop the interview before completion. All respondents have been anonymised and for confidentiality reasons, all company related identity issues have been masked in citations. The principle of reciprocity was applied by informing the study participants about the results of the study [27].

\section{Results}

The analysis with NVivo resulted in 637 codes (nodes) forming three main categories such as 'strategic choice, 'health programmes and 'sustainability', each with four to ten sub-categories, which in turn could be linked and associated with one core category labeled 'Development of health literate businesses' forming a grounded theory illustrated in Figure 1 and described in detail below.

\section{Developing health literate businesses}

Essentially, the study yielded a three-tiered grounded theory for developing health literate businesses within the realm of corporate social responsibility. To become a health literate business, the management must prioritize health and health literacy and form a strategic choice to integrate health as a corporate principle or value. Furthermore, the choice must be executed as build-in health programmes, rather than add-on health projects. Lastly, the build-in health-related business actions should be processed in a systematic and sustainable manner including focus on measurable indicators providing evidence on progress and efficiency as well as including an explicit focus on the 
Citation: Sørensen K, Czabanowska K, Brand H (2015) Developing Health Literate Businesses: A Qualitative Study. Occup Med Health Aff 3: 216. doi:10.4172/23296879.1000216

\section{Guideline for interviews: Health literacy activities for employees as part of corporate social responsibility (CSR)}

\section{Introduction}

Context: A joint venture has been launched in October 2010 to facilitate the introduction of health literacy as an issue for corporate social responsibility. The Joint Venture is set up within the umbrella of CSR Europe and the initiative is called "Health Literacy: Improving health knowledge among our employees and communities". It is a two year project lead by a steering group consisting of representatives from MSD, Nestle, Microsoft, Edenred, Maastricht University and CSR Europe.

Aim: The collaborative venture aims to explore how collaboration between companies and stakeholders can actively contribute to improving health literacy in Europe.

What is health literacy: Health literacy entails people's capacities, skills, knowledge, motivation and confidence to access, understand, appraise and apply health information to form judgments and take decisions in everyday life in terms of healthcare, disease prevention and health promotion to improve quality of life during the life course.

Purpose of interview: At the moment, the collaborative venture is developing a "Blueprint for Action in Health Literacy", based on good practices and case-studies. This management tool will help companies devise a framework for prevention, education on healthy choices and managing chronic diseases in the workplace. Your companies' possible program(s) on health literacy might constitute such good practice.

\begin{tabular}{|c|c|c|c|}
\hline & Key Topic & $\begin{array}{l}\text { Check whether the following points } \\
\text { are mentioned }\end{array}$ & Questions \\
\hline 1 & $\begin{array}{l}\text { Health literacy and/or health } \\
\text { projects/initiatives/programs in } \\
\text { company } \\
\text { This key topic is to be kept } \\
\text { short. } \\
\text { Sub questions are only to be } \\
\text { asked in case the information } \\
\text { provided by the company is not } \\
\text { clear or does not sound familiar }\end{array}$ & 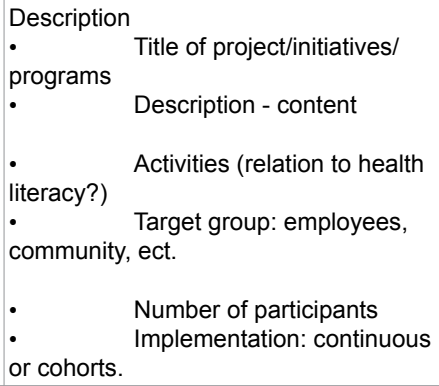 & $\begin{array}{l}\text { What kind of health programs do you offer your employees referring to health literacy? If } \\
\text { no programs offered on health literacy, what programs do you offer concerning health? } \\
\text { What is the aim of the program? } \\
\text { What are the specific activities performed or services provided? } \\
\text { Are there specific groups of employees you aim to include in the program? } \\
\text { How many people do participate? } \\
\text { Who do participate: are they primarily men or women, specific age? } \\
\text { Timeline: } \\
\text { When did the program start? How long is it in progress? } \\
\text { Does the program run continuously or in groups? }\end{array}$ \\
\hline 2 & Good Practice & Good practice & $\begin{array}{l}\text { Would you recommend any of the program(s) as an example for good practice? } \\
\quad \text { Why is it a good practice or not? Can you give reasons/examples? } \\
\text { What? Why? } \\
\text { Would you recommend running your program on a larger scale or expanding it to other } \\
\text { companies? } \\
\text { Which program or program elements would be suitable for upscaling? } \\
\text { Why? Please give reasons. } \\
\text { Where would you see difficulties or barriers in upscaling the program? } \\
\text { Where is adaptation/change needed? }\end{array}$ \\
\hline \multicolumn{4}{|c|}{ Program Details (To be Inquired when Companies' Program is Recommended as a Good Practice) } \\
\hline 3 & $\begin{array}{l}\text { Continuation of } 1 \text { above, } \\
\text { detailed description of planning } \\
\text { and resources }\end{array}$ & $\begin{array}{l}\text { Description } \\
\text { - Description - planning \& } \\
\text { resources }\end{array}$ & 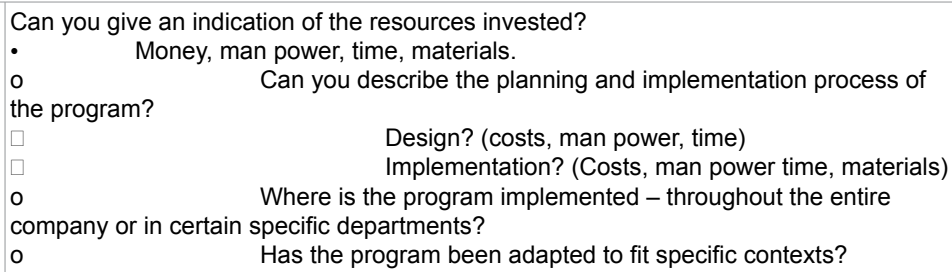 \\
\hline & Effectiveness/Efficiency & $\begin{array}{l}\text { Effectiveness/Efficiency } \\
\text { - Definition of effectiveness, } \\
\text { efficiency, success }\end{array}$ & $\begin{array}{l}\text { How do you determine the successfulness of the program? Which criteria are used to } \\
\text { judge the effectiveness of the program? } \\
\text { Examples of criteria: } \\
\text { Number of participants } \\
\text { Less accidents } \\
\text { Less sick leave } \\
\text { Behaviour change } \\
\text { Etc. } \\
\text { How/when is the program evaluated? } \\
\text { Continuously or at several pre-determined points in time (monthly, yearly)? } \\
\text { Who is involved in the evaluation: program implementers, individual } \\
\text { participants, participant representatives? } \\
\text { Method(s) of evaluation: discussion, questionnaires (open or closed } \\
\text { questions)? }\end{array}$ \\
\hline & Conclusion & $\begin{array}{l}\text { Thank you } \\
\text { Sending of material } \\
\text { Interested: Webinar November }\end{array}$ & $\begin{array}{l}\text { Thank you very much for your imput and contribution. } \\
\text { In case you are willing to share your program's material with us, please email to the } \\
\text { project coordinator. } \\
\text { In case you are interested in the results of this research and the progress of the } \\
\text { Collaborative Venture, more information will be provided during a Webinar in November } \\
2011 \text {, which you can sign up for through CSR Europe. }\end{array}$ \\
\hline
\end{tabular}

Table 1: Interview guide: Health literacy activities for employees as part of corporate social responsibility (CSR). 


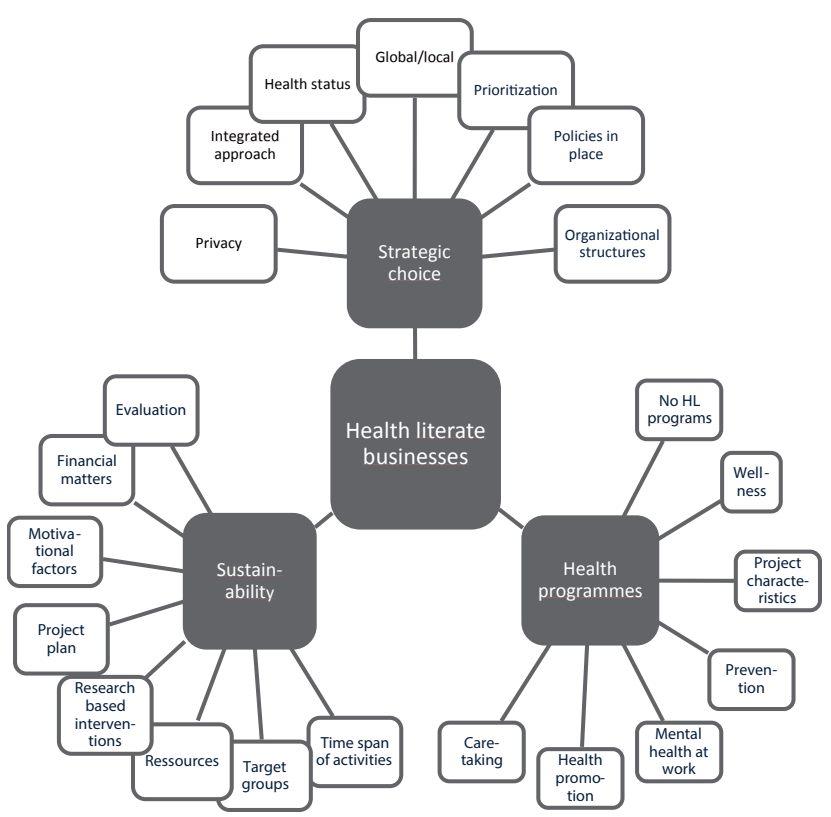

Figure 1: Grounded theory on how to develop health literate businesses.

advancement on health literacy as a component of health at work. Notably, the theory revealed a gap in health literacy efforts, hence there is a high potential for the advancement of health literacy to become part of health at work and strategic corporate actions. However, it requires a shift in the management mindset to integrate health as core business value in today's business world as a strategic, cost-efficient, transparent and measurable way to match the actual health and well-being needs in the workforce.

"What you need is a certain integrated approach that explains what is the business case for this kind of program, what is the benefit for the company, what is the benefit for the employees, and then you should start to develop a certain mid/long term program. A program that goes beyond a single event or a single campaign... This is much more than just a marketing campaign for health. It should be in the end part of the business".

\section{Health literacy as a strategic choice}

The first tier highlights the investment in health literacy as a strategic choice. The private sector needs to acknowledge as a prerequisite for the development of health literate businesses that investment in the health of employees is not only a "nice to have" attribute or philanthropic activity but it is a 'need to have' investment; and that health is as important as other core investment in business facilities.

The generated theory demonstrates that the advantages of investing in health and health literacy are underestimated by businesses, and there is a demand for a change of mind set toward health as a strategic core of the business. Only when companies realize that employees' health contributes to businesses' goals the business will be ready for change to commit to health and health literacy as a strategic choice in the realm of corporate social responsibility.

A systemic manner is required to integrate health and well-being to business structures and activities. The corporate backbone should include a strategy on health that enhances the well-being of employees and facilitates a health-oriented working environment; because ad-hoc events and information campaigns are not enough. Healthoriented environments can be facilitated by companies through the creation of internal structures, networks and platforms from which health programmes can be achieved. As a means of communication, information can be distributed through intranet and staff can volunteer or be appointed to execute the health programs, hence acting as health ambassadors within their company. Information must be easily accessible, and test can be implemented using self-tracking or selfmonitoring methods. The health programmes can be outsourced or executed in partnership with external stakeholders such as cooperation with health clinics, either internally or externally, to perform regular check-ups on employees. However, the issue of privacy, which especially in Europe due to data protection, influence corporate involvement in health, remains a sensible issue; as there is a sensitive balance between how much employers should know about the health of their employees and how much a company should offer in terms of supporting health programs.

In addition, to strengthen coherence, it is essential to retain a guiding global corporate vision and mission and stimulate local adaptation with reference to local ethical, social, political and cultural values regarding health at work.

"With all these types of programs, the big challenge is the same. It often starts as a charity thing: Let's invest in it and hope that it may do some good. In the end these types of programs are only sustainable if you can show the real benefit of the program. The benefit to the company, the business case, includes less sickness and better motivated people".

\section{Health programmes}

The second tier addresses the various reasons to engage in health programmes at work. Some convey that the target include to foster employees' health and safety by providing a healthy and safe working environments. Others link it to charity, productivity, satisfaction and effectiveness. Hence, it may not only be to reduce absenteeism, but to enhance the health conditions of the workforce as well. A unique feature regards the implementation of a more holistic approach to health by considering physical, mental, social, emotional and spiritual health. While current health practices involve focus on safety, disease prevention and promotion of (mental) health and well-being along with care-taking, few projects target the issue of health literacy on its own.

Generally, health projects can be accomplished in a variety of ways. Some involve yearly activities, while others employ weekly or monthly themes as a component of an integrated systematic approach. Certain companies plan deliberately activities with milestones such as World Aids Day, the Week of Cancer, and days related to special diseases as guidelines for their efforts. Other health events include marathons, football competitions, bicycling races, and mass vaccination days. Employees are often challenged to engage in an endeavor to improve their health - stop smoking, go on diet, lower cholesterol, do more exercise and were encouraged to make teams or compete with each other. The list of possibilities is endless; yet it is of importance that the activities undertaken are matching the needs of the people involved. Otherwise, there will be a mismatch between resources spend by the company and the outcome of the involvement of the employee. Several kind of incentives are often used to stimulate participation such as free fruit, free access to sport facilities or free smoking cessation courses.

"Each employee is encouraged to create a team of other employees for whatever wellness challenge is at hand. Recently, we just did one that was a broad wellness challenge on becoming more active and then also 
eating healthier and also losing weight as that is a priority. It is more about healthy weight than it is about losing weight... This was a 3-month challenge that went on. Employees were encouraged to log all of their information, and there was an interactive social platform where people could challenge each other to other wellness activities. At the end, if you completed everything you were incentivized with a gift-card for an online store".

\section{Sustainability}

The third tier refers to sustainability as an important factor for the development of health literate businesses. Hence, the investment in health literacy should involve systematic and sustainable considerations and choices concerning the target group and their needs, the motivational factors in play, the required priorities, the policies enacted to facilitate actions, the human and financial resources needed, the time span of activities, the organization and structures required and the evaluation and quality insurance means. However, on multiple occasions, it is not possible to judge the quality of many existing health programmes. Additionally, it is rare that the long lasting effect of the programs can be well explained. Thus, it is apparent from the generated theory that although most companies execute health programmes, there is a lack of transparency in terms of the use of priorities and resources.

While, a majority of the health programs identified focus on food and nutrition, medical examinations and health check-ups as well as preventive measures such as smoking cessation and stress management, only few interviewees can rationalize the reasoning behind these priorities. Notably, the initiatives are often closely linked to the core business of the company, e.g. food industries significantly focus on nutrition. Nevertheless, motivational factors and incentives such as wellness bonuses, competitions and personal development opportunities are consistent phenomena, which are utilized to attract employees to engage in health programs and to increase awareness and involvement. Free entry and membership to fitness clubs and free fruit and water are also frequently used incentives. Most programs are not compulsory. Yet, the managers are implied to encourage and participate as role models in the anticipation of strengthening the participation among their employees.

Currently, the evidence and efficiency of the health programmes are rarely described. Only little information is provided concerning scientific evidence, methods or concepts. References to general knowledge about risk factors and the wide spread prevalence of noncommunicable diseases are provided, however it is often perceived as a struggle to make the best match between actual needs and programmes to provide an optimal solution for the employees.

While it is emphasized that policies need to be enacted to ensure health management in businesses, only few companies pursue thorough, formalized, integrated policies rather than outlines of health projects. The theory demonstrates that, in order to achieve improved health literacy outcomes at work, a systematic focus on the needs within the workforce to improve health-related knowledge, motivation and competences of the employees is required. In the view of creating sustainability assessment, monitoring and evaluation mechanisms are essential to follow the progress related to specific indicators related to health outcomes. It is imperative that initiatives are targeted to the specific needs of individuals, and businesses should depart from the 'one size fits all' attitude when communicating to their employees about health.

"The... health strategy will then have a vision, and a mission and an implementation plan. Our vision and our mission entail to deliver health to all our employees and we have three areas. So it is obvious that the very first and important one is occupational health and safety, within the strategy. The second one would be health promotion. Including promoting health or creating awareness around health and doing tests all the way to understanding your treatment and all of that. And the third one is that we have an epidemiology section... And the plan to implement all these things will then have these overarching targets, one-year and fiveyear targets, and then we measure a certain set of parameters...across the world".

\section{Discussion}

As most people spend a considerable amount of time and energy at work, businesses can play an essential role in promoting and sustaining their employees' quality of life and healthy living. The study makes a unique contribution to the field of health at work as it suggests that developing health literate businesses in the realm of CSR is a way to respond to the demands for smart growth as requested by the EU in Europe 2020 [11] and health-oriented strategies such as Charter for Healthy Living [9], Health 2020 [18] and Together for Health [17]. The use of thematic analysis to develop a grounded theory deepens the understanding of how to develop health literate businesses and emphasize the necessity to incorporate health literacy into health at work strategies as a core priority and settled value within the business model; rather than as a component of add-on health projects. Furthermore, in accordance with the generated theory, the strategic focus on health literacy business actions should be two-sided including a dual responsibility which involves employees as individuals as well as the management teams to advance health literacy. In this regard the theory pledge for a mind-shift towards a stronger strategic integration of health and well-being. The integrative mind shift has occurred in terms of safety which is highly regulated; however, improving health and well-being for employees have yet to be anchored into businesses' core policy, guidelines and actions in a sustainable manner [16]. The identified need to develop health literate businesses is not a feature on its own, a similar process is taking place in the healthcare systems, where the process of developing organizational attributes is also on the agenda [28].

The work place constitutes a unique setting for empowerment and growth. It is a part of the daily life routine that provides opportunities for specific, targeted initiatives that match the needs of the individual employees. As in DNA, the strength is achieved in the string when the blocks are matched correctly. The process of systematic approach, measurement, comfortable fit and further evaluation is the key aspect of success for the integration of health literacy in strategic corporate efforts concerning healthy lives and health at work. As such, health literacy as an outcome of the corporate DNA can be an important building block to boost knowledge, motivation and competency of employees to assist them in making informed decisions in terms of health. It is also an essential building block toward creating a health literacy-friendly working environment. The type and content of the programs should meet the needs, be evidence-based, of good quality and targeted to the people involved.

The CSR platform is convenient for discovering new frontiers, especially when the frontiers include aspects related to building the foundations of sustainable and efficient organizations [29]; an aspect which has been supported by the theory generated in the current study. Preferably, the priority given to climate change and sustainability as part of the CSR agenda will, in the future, be shared with health. A paradigm 
Citation: Sørensen K, Czabanowska K, Brand H (2015) Developing Health Literate Businesses: A Qualitative Study. Occup Med Health Aff 3: 216. doi:10.4172/23296879.1000216

Page 6 of 7

shift will be reaching the tipping point when few become many to integrate health literacy as part of health at work efforts. Essentially, it is important to recognize that health literacy, health at work and healthy living form not only a segment of corporate social responsibility but also of corporate social opportunity in order to execute the necessary changes [30]. To increase the velocity of change the present study paves the way with concrete recommendations that include to:

-Integrate the advancement of health literacy as a strategic choice in the long-term core corporate management strategy concerning healthy living and health at work to ensure sustainable development and impact on health literacy and the health of the workforce.

- Measure health and health literacy and prepare needs assessments to ensure a better fit in terms of programs and actual health needs within the work force.

-Provide quality programs and activities that match the needs of the workforce and are adapted to the local conditions and settings to create long lasting effects.

-Provide ongoing evaluations of actions and expand the possibilities for further growth and empowerment when results are achieved to ensure continuous progress and motivation.

-Find a balance between individual choice and business interests in concordance with ethical and social values linked to the specific cultural and political settings in which the company is situated.

Certain limitations are worth noting for the current study; when applying Lincoln and Guba's qualitative validation criteria [26]. The recruitment of key informants was a challenge. A reason for the $60 \%$ nonresponse was related to difficulties of reaching the appropriate people with the concrete knowledge about health programs within the companies. It may imply that certain aspects of health at work are not represented in the theory, however since the profiles of the companies participating since varied considerably, and with a slight overweight of companies operating in the field of health and wellbeing; the nonresponse effect is assumed to be of minor effect. While the majority of interviews provided fruitful insights into current health activities, less transparency was pursued concerning financial and structural aspects of business actions on health. Therefore, these aspects should be further investigated in the future. While the findings of the study may not be empirically generalizable due to the specific context of the study design which, for example, implied recruitment of participants through CSR Europe, the evidence concerning health literacy as a strategic business action in the realm of corporate social responsibility is in general theoretically transferable. The credibility and dependability of the study have been strengthened by providing a visual model combined with 'thick' descriptions of the findings to enhance transparency and clarity concerning the generated theory. Finally, the confirmability of findings was assured through the development and adherence of a transparent work plan and through the engagement of staff from both CSR Europe and Maastricht University in the data collection and data analysis.

\section{Conclusion}

The grounded theory on the development of health literate businesses in the realm of corporate social responsibility supports the call for strategic change emphasized recently by the WEF, the EU and WHO. Furthermore, the grounded theory can serve as basis for the development of a new action framework. The findings clearly indicate that health-related decisions and actions are no longer related solely to the free fruit basket and fitness-room for employees as part of health projects - instead, the decisions in the boardroom are of even more importance to strengthen health at work as a core business value. Essentially, the crucial investment from management level in health literacy to support healthy living as part of the core corporate social responsibility can increase the well-being and health status for the individual and support corporate level outcomes for the benefit of the company as well as society as a whole.

\section{References}

1. Sørensen K, Brand H (2011) Health literacy--a strategic asset for corporate social responsibility in Europe. Journal of health communication 16: 322-337.

2. Berkman ND, Sheridan SL, Donahue KE, Halpern DJ, Crotty K (2011) Low health literacy and health outcomes: an updated systematic review. Annals of Internal Medicine 155: 97-107.

3. Paasche-Orlow MK, Parker RM, Gazmararian JA, Nielsen-Bohlman LT, Rudd RR (2005)The prevalence of limited health literacy. Journal of General Internal Medicine, Blackwell Science Inc 20: 175-184.

4. HLS-EU Consortium (2012) Comparative report on health literacy in eight EU member states. The European Health Literacy Project 2009-2012.

5. Clark BR (2011) Using Law to Fight a Silent Epidemic: The Role of Health Literacy in Health Care Access, Quality, and Cost. Annals of Health Law 20 253.

6. Kickbusch I Maag D (2008) Health Literacy in Heggenhougen K, Quah S (Eds.), International Encyclopedia of Public Health, Academic Press, San Diego 3: 204-211.

7. Sørensen K, Van den Broucke S, Fullam J, Doyle G, Pelikan et al. (2012)Health literacy and public health: a systematic review and integration of definitions and models. BMC public health 12: 80.

8. European Commission (2011) Communication from the commission to the European Parliament, the Council, the European Economic and Social Committee and the Committee of the Regions. A renewed EU strategy 2011-14 for Corporate Social Responsibility.

9. World Economic Forum prepared in collaboration with Bain \& Company (2013) Charter for Healthy Living. A report from the World Economic Forum's Healthy Living Initiative, Geneva.

10. World Health Organisation (2008) Workers Health is a Corporate Socia Responsibility. Environmental Health Update. Sustainable Development and Healthy Environments 3: 5 .

11. European Commission (2010) Europe 2020 Brussels.

12. Ouye JA (2011) Five Trends that Are Dramatically Changing Work and the Workplace. New Ways of Working and Knoll, Inc.

13. Deloitte (2009) Why change now ? Preparing for the workplace of tomorrow Executive Summary. Deloitte.

14. Lynch WD (2002) What is a healthy employee worth. Absolute advantage 16 19.

15. World Economic Forum (2012) The Workplace Wellness Alliance. Investing in a sustainable workforce; in collaboration with the Boston Consulting Group Cologny/Geneva.

16. Montero MJ, Araque RA, Rey JM (2009) Occupational health and safety in the framework of corporate social responsibility. Safety Science 47: 1440-1445.

17. European Commission (2007) Together for Health: A Strategic Approach for the EU 2008-2013, Brussels.

18. World Health Organisation's European Office (2012) Health 2020: a European policy framework supporting action across government and society for health and well-being, Copenhagen.

19. Cresswell J (2009) Research Design: Qualitative, Quantitative, and Mixed Approaches, SAGE, Thousand Oaks, CA.

20. Ryan GW, Bernard HR(2003) “Field Methods”, Field Methods 15: 85-109.

21. Strauss A, Corbin J (1990) Basics of Qualitative Research: Techniques and Procedures for Developing Grounded Theory, Sage Publications.

22. http://www.csreurope.org/. 
Citation: Sørensen K, Czabanowska K, Brand H (2015) Developing Health Literate Businesses: A Qualitative Study. Occup Med Health Aff 3: 216. doi:10.4172/2329. 6879.1000216

Page 7 of 7

23. Berg BL, Lune H (2011) Qualitative Research Methods for the Social Sciences (8thedn) Pearson.

24. Johnson R, Robert B, Christensen LB (2012) Educational Research Quantitative, Qualitative, and Mixed Approaches, SAGE Publications, Inc, Thousand Oaks, CA.

25. Miles MB, Huberman AM (1994) Qualitative Data Analysis: An Expanded Sourcebook, SAGE Publications, Inc, (2ndedn).

26. Lincoln Y, Guba E (1985) Naturalistic Inquiry, Sage Publications, New Bury
Park.

27. Ulin PR, Robinson ET, Tolley EE (2004) Qualitative Methods in Public Health: A Field Guide for Applied Research, Jossey-Bass.

28. Brach C, Dreyer B, Schyve P, Hernandez LM, Baur C, et al. (2012) Attributes of a Health Literate Organization, New York.

29. Scott J (2009) Managing the new frontiers. An introduction to the fundamentals.

30. Grayson D (2004) Corporate Social Opportunity: Seven steps to make corporate social responsibility work for your business, Greenleaf, United Kingdom. 